\title{
KEKERASAN DALAM PACARAN DAN KECEMASAN REMAJA PUTRI DI KABUPATEN PURWOREJO
}

\author{
Suci Musvita Ayu ${ }^{1}$, Mohammad Hakimi ${ }^{2}$, Elli Nur Hayati ${ }^{3}$ \\ ${ }^{1}$ Fakultas Kesehatan Masyarakat, Universitas Ahmad Dahlan, Yogyakarta \\ ${ }^{2}$ Departemen Obstetrik dan Ginekologi, Fakultas Kedokteran, Universitas Gadjah Mada \\ ${ }^{3}$ Fakultas Psikologi, Universitas Ahmad Dahlan, Yogyakarta
}

\begin{abstract}
Abstact
Background: Gender-based violence in Indonesia is that many cases occur. Since 1998, violence in dating the Rifka Annisa Women's Crisis Center is a case of the second largest after the violence against wives. Emotional violence in dating can lead to psychological effects, and one of the psychological effect is the occurrence of anxiety. Anxiety itself can cause psychological effects. The aimof the research to determine the relationship between violence on anxiety in dating young women in Purworejo District.

Methods: Cross Sectional study design to girls at SMK SMAN 3 and 6 of Dating Violence (KDP) in Purworejo District 120.

Results: The Violence of the most experienced young women is sexual violence because of being kissed forcefully by $34.71 \%$. Physical violence from being hit by $30.83 \%$. Violence economy because without the willingness to buy credit for as much as $25.83 \%$ and $17.50 \%$ experienced emotional abuse because they feel insulted about the treatment the couple who make it a laughing stock. Age has an effect on anxiety, where anxiety is more risky in women who experience sexual violence against a background of 14-16 years of middle age.

Conclusion: There was a significant association between dating violence and anxiety in young women in Purworejo District ( $p=0,0014 \mathrm{RP}=3,1$ dan $95 \% \mathrm{Cl}=1,5-6,3)$.
\end{abstract}

Keywords: Dating Violence, Anxiety, Adolescent

\section{PENDAHULUAN}

Masyarakat banyak yang peduli tentang kekerasan yang terjadi di dalam rumah tangga (domestic violence), namun masih sedikit yang peduli pada kekerasan yang terjadi pada mereka yang sedang berpacaran (Kekerasan Dalam Pacaran/KDP) atau Dating Violence. Perempuan lebih banyak menjadi korban dibandingkan laki-laki karena pada dasarnya kekerasan ini terjadi karena adanya ketimpangan kekuasaan antara laki-laki dan perempuan yang dianut oleh masyarakat luas. Ketidakadilan dalam hal gender selama ini telah terpatri dalam kehidupan sehari-hari, bahwa seorang perempuan biasa dianggap sebagai makhluk yang lemah, penurut, pasif, mengutamakan kepentingan laki-laki dan lain sebagainya, sehingga dirasa "pantas" menerima perlakuan yang tidak wajar atau semena-mena.

Kekerasan yang terjadi dalam relasi personal perempuan ini biasanya terdiri dari beberapa jenis, misalnya serangan terhadap fisik, mental/psikis, ekonomi dan seksual. Segi fisik, kekerasan yang dilakukan seperti memukul, meninju, menendang, menjambak, mencubit dan lain sebagainya, sedangkan kekerasan terhadap mental seseorang biasanya seperti cemburu yang berlebihan, pemaksaan, memaki-maki di depan umum dan lain sebagainya. ${ }^{1}$ Kekerasan Dalam Pacaran (KDP) berkaitan erat dengan kesehatan baik jangka pendek maupun jangka panjang, yang meliputi: perlukaan fisik, gangguan saluran pencernaan, sindroma nyeri kronik, dan perilaku depresi atau ancaman bunuh diri. 
Kekerasan dalam hal ekonomi jika pasangan sering pinjam uang atau barang-barang lain tanpa pernah mengembalikannya, selalu minta ditraktir, dan lain-lain. Jika dipaksa dicium oleh pacar, jika ia mulai meraba-raba tubuh atau ia memaksa untuk melakukan hubungan seksual, maka ia telah melakukan kekerasan yang termasuk dalam kekerasan seksual. Umumnya pemerkosaan yang terjadi dalam masa pacaran (Dating Rape) diawali oleh tindakan kekerasan yang lain. ${ }^{(2)}$ Kecemasan adalah respon terhadap suatu ancaman yang sumbernya tidak diketahui, internal, samar-samar atau konfliktual. ${ }^{3}$

Indonesia pada tahun 2003 kasus kekerasan dalam pacaran berjumlah 266 kasus dan memiliki 303 lembaga yang memberi layanan kepada perempuan korban kekerasan, salah satunya adalah organisasi yang tergabung dalam Women Crisis Center terdapat 137 organisasi di Indonesia, 134 Ruang Pelayanan Khusus (RPK) dan 32 Rumah Sakit yang membuka pelayanan khusus bagi perempuan dan anak korban kekerasan, namun perempuan korban kekerasan di Indonesia masih banyak terjadi. ${ }^{4}$

Angka kekerasan dalam pacaran di Sumatera Selatan yang dilaporkan kepada Women's Crisis Centre Palembang tahun 2009 sebanyak 52 kasus. Jumlah ini meningkat dibandingkan dengan tahun 2008 yang sebanyak 22 kasus. Meningkatnya angka kekerasan dalam pacaran karena banyak korban (perempuan) yang dipaksa atau dibujuk melakukan hubungan intim saat berpacaran. $^{5}$

Berdasakan data kasus kekerasan dalam pacaran di Rifka Annisa (WCC) Yogyakarta tahun 1999 sebesar 50 kasus $(14,33 \%)$ dan meningkat pada tahun 2001 sebanyak 103 kasus $(26,08 \%)$. Wilayah domisili korban kekerasan yang paling banyak terdapat di Daerah Istimewa Yogyakarta sebanyak 18 kasus dari pada kabupaten lain. Pada usia ini perempuan memiliki ikatan kuat dengan pasangannya (pacarnya) sehingga perempuan menganggap bahwa kekerasan yang dialami adalah hal yang wajar. Oleh karena itu, peneliti ingin melihat gambaran kekerasan dalam pacaran terhadap kecemasan remaja putrid di Kabupaten Purworejo.

\section{METODE PENELITIAN}

Jenis penelitian ini adalah jenis penelitian analitik dengan studi observasional menggunakan rancangan penelitian cross sectional. Penelitian dilakukan di Kabupaten Purworejo yaitu di SMKN 3 dan SMAN 6. Subjek dalam penelitian ini adalah SMAN 6 sebanyak 78 siswi dan SMKN 3 sebanyak 42 siswi. Pengambilan sampel menggunakan metode simple random sampling berjumlah 120 orang.

Variabel bebas menggunakan alat ukur kuesioner yang dibagi atas sub variabel seperti kekerasan fsik no. 1 sampai 5 , kekerasan seksual no. 6 sampai 11 , kekerasan emosi 12 sampai 19 dan kekerasan ekonomi 20-25 yang merupakan modifikasi dari WHO (2005). Instrumen yang digunakan tidak perlu dilakukan uji validitas dan reliabilitas oleh karena telah digunakan oleh peneliti sebelumnya. ${ }^{(6)}$

Wawancara menggunakan pedoman wawancara terstruktur (interview guide) yang telah dipersiapkan terlebih dahulu. Pelaksanaan penelitian kualitatif, peneliti didampingi oleh tenaga konselor pendamping kasus kekerasan dalam pacaran. 


\section{HASIL DAN PEMBAHASAN}

\section{A. Hasil Penelitian}

\section{1) Analisis Univariabel}

Hasil analisis univariabel ini disajikan pada Tabel 1. berupa distribusi frekuensi dari karakteristik responden berdasarkan: usia, lama pacaran dan sumber informasi.

Tabel 1. Distribusi Karakteristik Subjek Penelitian Berdasarkan Usia, Lama Pacaran dan Sumber

\begin{tabular}{lcc}
\hline \multicolumn{1}{c}{ Variabel } & Frekuensi & $\%$ \\
\hline KDP & & \\
\hline - Yang mengkami KDP & 35 & 29,17 \\
- Tidak mengalami KDP & 85 & 70,83 \\
\hline Kecemasan & & \\
\hline - Tinggi & 17 & 14,17 \\
- Sedang & 85 & 70,83 \\
- Rendah & 18 & 15 \\
\hline Usia & & \\
\hline - Remaja Pertengahan & 98 & 81,87 \\
- Remaja Lanjut & 22 & 18,33 \\
\hline Lama Pacaran & & \\
\hline - $\geq 2$ Tahun & 25 & 20,83 \\
- $\leq 1$ Tahun & 95 & \\
\hline Sumber Informasi & & 67,17 \\
\hline - Bukan dari orang tua & 81 & 32,50 \\
- Dari orang tua & 39 &
\end{tabular}

Berdasarkan tabel 1, menunjukkan bahwa persentase remaja yang mengalami kekerasan dalam pacaran sebesar $29,17 \%$. Tingkat kecemasan yang dialami oleh remaja putri dalam kategori sedang sebesar 70,83\%. Persentase kekerasan dalam pacaran terjadi pada usia pertengahan sebesar $81,87 \%$. Frekuensi remaja yang mengalami kekerasan dalam pacaran adalah kurang dari satu tahun dan atau 1 tahun sebesar $79,17 \%$. Selain itu, Responden yang mengakses media massa (media cetak dan media elektronik) untuk memperoleh atau mencari informasi kesehatan reproduksi khususnya kekerasan dalam pacaran sebesar 81 responden $(67,50 \%)$. 


\section{2) Analisis Bivariabel}

a) Analisis bivariabel antara variabel bebas dan variabel luar dengan variabel terikat

Tabel 2. Hubungan Kekerasan Dalam Pacaran Dan Tingkat Kecemasan Remaja Putri

\begin{tabular}{|c|c|c|c|c|c|c|c|}
\hline \multirow[b]{2}{*}{ Variabel } & \multicolumn{3}{|c|}{ Tingkat Kecemasan } & \multirow[b]{2}{*}{$x^{2}$} & \multirow[b]{2}{*}{$\rho$} & \multirow[b]{2}{*}{$\mathrm{RP}$} & \multirow[b]{2}{*}{ Cl 95\% } \\
\hline & $\begin{array}{l}\text { Tinggi } \\
\mathrm{n}(\%) \\
\end{array}$ & $\begin{array}{l}\text { Sedang } \\
\mathrm{n}(\%)\end{array}$ & $\begin{array}{c}\text { Rendah } \\
\mathrm{n}(\%) \\
\end{array}$ & & & & \\
\hline \multirow{3}{*}{$\begin{array}{l}\text { KDP } \\
\text { - Mglm } \\
\text { KDP }\end{array}$} & & & & & & & \\
\hline & 11 & 22 & 2 & & & & \\
\hline & $(31,43)$ & $(62,86)$ & $(5,71)$ & 13,7 & 0,0014 & $\begin{array}{l}3,1 \\
12\end{array}$ & $\begin{array}{c}1,5-6,3 \\
1-13\end{array}$ \\
\hline \multirow{2}{*}{$\begin{array}{l}\text { - Tdk } \\
\text { Mglm } \\
\text { KDP }\end{array}$} & 6 & 63 & 16 & & & & \\
\hline & $(7,06)$ & $(74,12)$ & $(18,82)$ & & & & \\
\hline
\end{tabular}

Berdasarkan tabel 2, ditemukan remaja yang mempunyai tingkat kecemasan tinggi dan mengalami kekerasan dalam pacaran sebanyak $31,43 \%$. Kekerasan dalam pacaran berhubungan secara signifikan dengan kecemasan $(p=0,0014 \mathrm{RP}=3,1$ dan $95 \% \mathrm{Cl}=1,5-6,3)$. Hasil ini dapat diinterpretasikan bahwa prevalensi remaja yang mengalami kekerasan dalam pacaran dan mengalami kecemasan sebesar 3,1 kali. Hasil uji statistik menunjukkan hubungan yang bermakna antara kekerasan dalam pacaran dengan kecemasan. Dengan demikian hipotesis ini dapat diterima.

Tabel 3. Variabel Bebas dan Variabel Luar

\begin{tabular}{|c|c|c|c|c|c|c|c|}
\hline \multirow[b]{2}{*}{ Variabel } & \multicolumn{3}{|c|}{ Tingkat Kecemasan } & \multirow[b]{2}{*}{$x^{2}$} & \multirow[b]{2}{*}{$\rho$} & \multirow[b]{2}{*}{$\mathrm{RP}$} & \multirow[b]{2}{*}{$\mathrm{Cl} 95 \%$} \\
\hline & $\begin{array}{l}\text { Tinggi } \\
\mathrm{n}(\%)\end{array}$ & $\frac{\text { Sedang }}{\mathrm{n}(\%)}$ & $\frac{\text { Rendah }}{\mathrm{n}(\%)}$ & & & & \\
\hline $\begin{array}{l}\text { Usia } \\
\text { Remaja }\end{array}$ & & & & & & & \\
\hline $\begin{array}{l}\text { - Rmj MID } \\
\text { - Rmj Old }\end{array}$ & $\begin{array}{c}9 \\
(9,18) \\
8 \\
(26,36) \\
\end{array}$ & $\begin{array}{c}73 \\
(74,49) \\
12 \\
(54,55) \\
\end{array}$ & $\begin{array}{c}16 \\
(16,33) \\
2 \\
(9,09) \\
\end{array}$ & 11 & 0.0228 & $\begin{array}{l}0,5 \\
0,9\end{array}$ & $\begin{array}{l}0,2-0,8 \\
0,7-1,2\end{array}$ \\
\hline $\begin{array}{l}\text { Lama } \\
\text { Pacaran }\end{array}$ & & & & & & & \\
\hline $\begin{array}{l}\cdot \geq 2 \text { thn } \\
-\leq 1 \text { thn }\end{array}$ & $\begin{array}{c}6 \\
(24) \\
11 \\
(11,58)\end{array}$ & $\begin{array}{c}17 \\
(68) \\
68 \\
(71,58)\end{array}$ & $\begin{array}{c}2 \\
(8) \\
16 \\
(16,84)\end{array}$ & 3,3 & 0.0964 & $\begin{array}{l}1,8 \\
1,1\end{array}$ & $\begin{array}{l}1,0-3,0 \\
1,0-1,3\end{array}$ \\
\hline Smbr_Info & & & & & & & \\
\hline $\begin{array}{l}\text { - } \neq \text { Ortu } \\
\text { - Ortu }\end{array}$ & $\begin{array}{c}8 \\
(9,88) \\
9 \\
(23,08) \\
\end{array}$ & $\begin{array}{c}59 \\
(72,84) \\
26 \\
(66,67) \\
\end{array}$ & $\begin{array}{c}14 \\
(17,28) \\
4 \\
(10,26)\end{array}$ & 4,2 & 0.0625 & $\begin{array}{l}0,5 \\
0,9\end{array}$ & $\begin{array}{l}0,3-1,0 \\
0,7-1,1\end{array}$ \\
\hline
\end{tabular}

Hasil analisis pada tabel 3 di atas menunujukkan bahwa usia menunjukkan hubungan yang signifikan $(p=0,0228)$ merupakan variabel potensial confounding, sedangkan lama pacaran dan sumber informasi tidak menunjukkan hubungan yang signifikan $(p=0,09$ dan $p=0,06)$ sehingga tidak berpeluang menjadi confounding. 
b) Analisis bivariabel antara variabel terikat dan variabel luar

Berdasarkan tabel 4 di bawah ini persentase remaja yang mengalami kekerasan dalam pacaran pada usia remaja pertengahan sebanyak $26,53 \%$. Hasil analisis antara usia remaja dengan kekerasan dalam pacaran menunjukkan hubungan yang tidak bermakna $(p=0,18)$. Prevalensi remaja akhir yang mengalami kekerasan dalam pacaran sebesar 1,8 kali.

Tabel 4. Pengaruh Kekerasan dalam Pacaran Dengan Usia, Lama Pacaran dan Sumber Informasi

\begin{tabular}{|c|c|c|c|c|c|c|}
\hline \multirow{3}{*}{ Variabel } & \multicolumn{2}{|c|}{ KDP } & \multirow{3}{*}{$x^{2}$} & \multirow{3}{*}{$\rho$} & \multirow{3}{*}{$\mathrm{RP}$} & \multirow{3}{*}{ Cl 95\% } \\
\hline & $\begin{array}{c}\text { Mengalami } \\
\text { KDP }\end{array}$ & $\begin{array}{l}\text { Tdk Mglmi } \\
\text { KDP }\end{array}$ & & & & \\
\hline & $\mathrm{n}(\%)$ & $\mathrm{n}(\%)$ & & & & \\
\hline \multicolumn{7}{|l|}{ Usia Remaja } \\
\hline Rmj MID & $\begin{array}{c}26 \\
(26,53)\end{array}$ & $\begin{array}{c}72 \\
(73,47)\end{array}$ & 1,8 & 0,18 & 0,6 & $0,4-1,2$ \\
\hline Rmj Old & $\begin{array}{c}9 \\
(40,91) \\
\end{array}$ & $\begin{array}{c}13 \\
(59,09) \\
\end{array}$ & & & & \\
\hline \multicolumn{7}{|c|}{ Lama Pacaran } \\
\hline$\geq 2$ thn & $\begin{array}{c}10 \\
(40)\end{array}$ & $\begin{array}{c}15 \\
(60)\end{array}$ & 1,8 & 0,18 & 1,52 & $0,8-2,7$ \\
\hline$\leq 1$ thn & $\begin{array}{c}25 \\
(26,32) \\
\end{array}$ & $\begin{array}{c}70 \\
(73,68) \\
\end{array}$ & & & & \\
\hline \multicolumn{7}{|l|}{ Smbr_Info } \\
\hline$\neq$ Ortu & $\begin{array}{c}19 \\
(23,46)\end{array}$ & $\begin{array}{c}62 \\
(76,54)\end{array}$ & 3,9 & 0,047 & 0,6 & $0,3-0,9$ \\
\hline Ortu & $\begin{array}{c}16 \\
(41,03)\end{array}$ & $\begin{array}{c}23 \\
(58,97) \\
\end{array}$ & & & & \\
\hline
\end{tabular}

Hasil uji statistik menunjukkan hubungan yang bermakna antara sumber informasi bukan dari orang tua tetapi dari media massa (media cetak dan media elektronik) dengan remaja yang mengalami kekerasan dalam pacaran $(p=0,04)$.

Tabel 5. Bentuk Kekerasan yang Dialami Oleh Remaja Putri

\begin{tabular}{lcc}
\hline Kekerasan & Frekuensi & Percent \\
\hline Fisik & 37 & 30,38 \\
\hline Seksual & 41 & 34,71 \\
\hline Emosi & 21 & 17,50 \\
\hline Ekonomi & 31 & 25,83 \\
\hline
\end{tabular}

Berdasarkan hasil tabulasi data yang digunakan pada tabel 5 , ditunjukkan bahwa $34,17 \%$ remaja putri di Kabupaten Purworejo mengalami kekerasan seksual karena dicium paksa, sebanyak 30,83\% mengalami kekerasan fisik karena dipukul, sebanyak 25,83\% mengalami kekerasan ekonomi karena tanpa kerelaan membelikan pulsa, dan sebanyak $17,50 \%$ mengalami kekerasan emosi karena merasa tersinggung atas perlakuan pasangan yang menjadikannya sebagai bahan tertawaan di depan umum. 
c) Analisa Multivariabel

Tabel 6. Perkiraan Nilai Rasio Prevalensi Melalui Pemodelan Regresi Logistik, Kekerasan dalam Pacaran, Usia, Lama Pacaran dan Sumber Informasi Remaja Putri

\begin{tabular}{|c|c|c|c|c|}
\hline \multirow{2}{*}{ Variabel } & Model 1 & Model 2 & Model 3 & Model 4 \\
\hline & OR $(95 \% \mathrm{Cl})$ & OR $(95 \% \mathrm{Cl})$ & OR $(95 \% \mathrm{Cl})$ & OR $(95 \% \mathrm{Cl})$ \\
\hline \multicolumn{5}{|l|}{$\begin{array}{l}\text { Kekerasan } \\
\text { dalam } \\
\text { pacaran }\end{array}$} \\
\hline $\begin{array}{l}\text { - Ya } \\
\text { - Tidak }\end{array}$ & $\begin{array}{c}6(2-18)^{*} \\
1\end{array}$ & $\begin{array}{c}5,7(1,8-17)^{*} \\
1\end{array}$ & $\begin{array}{c}5,6(1,8-17)^{*} \\
1\end{array}$ & $\begin{array}{c}5,4(1,7-16)^{*} \\
1\end{array}$ \\
\hline \multicolumn{5}{|l|}{ Usia } \\
\hline $\begin{array}{l}\text { - } 14-16 \\
\text { - } 17-20\end{array}$ & & $\begin{array}{c}0,19(0,1-0,6)^{*} \\
1\end{array}$ & & \\
\hline \multicolumn{5}{|l|}{$\begin{array}{l}\text { Lama } \\
\text { pacaran }\end{array}$} \\
\hline $\begin{array}{l}\text { - lebih dari } 2 \\
\text { thn } \\
\text { - kurang } \\
\text { dari } 1 \text { thn } \\
\end{array}$ & & & $\begin{array}{c}2,0(0,6-6,6) \\
1 \\
\end{array}$ & \\
\hline \multicolumn{5}{|l|}{$\begin{array}{l}\text { Sumber } \\
\text { Informasi }\end{array}$} \\
\hline $\begin{array}{l}\text { - Bukan dari } \\
\text { ortu } \\
\text { - dari ortu }\end{array}$ & & & & $\begin{array}{c}0,5(0,2-1,4) \\
1 \\
\end{array}$ \\
\hline Devience & 0,112 & 0,187 & 0,125 & 0,130 \\
\hline R2 & 86,9509204 & 79.6177208 & 85.657252 & 85.154328 \\
\hline $\mathrm{N}$ & 120 & 120 & 120 & 120 \\
\hline
\end{tabular}

* $=$ signifikan pada $p<0,05$

Model 1 dibuat untuk melihat hubungan variabel bebas (kekerasan dalam pacaran) dengan variabel terikat (kecemasan). Hasil analisis menunjukkan terdapat hubungan yang bermakna secara ststistik dan praktis antara kekerasan dalam pacaran dengan kecemasan remaja putri. Sementara remaja yang mendapat kekerasan dalam pacaran mempunyai kemungkinan 6 kali lebih besar untuk mengalami kecemasan. Model ini memberikan kontribusi terjadinya kecemasan sebesar $11 \%$.

Model 2 menggambarkan hubungan antara kekerasan dalam pacaran dengan kecemasan dengan memasukkan usia remaja putri. Hasil analisis menunjukkan bahwa ada hubungan yang bermakna statistik dan praktis. Hasil analisis model 2 menunjukkan bahwa usia remaja putri mempunyai kemungkinan 0,19 kali lebih besar untuk mengalami kecemasan. Model ini memberikan kontribusi terjadinya kecemasan sebesar $18,7 \%$.

Model 3 menggambarkan hubungan antara kekerasan dalam pacaran dengan kecemasan dengan melibatkan lama pacaran. Hasil analisis menunjukkan kekerasan dalam pacaran memiliki hubungan yang bermakna dengan kecemasan. Namun dengan melibatkan variabel lama pacaran tidak ada hubungan yang bermakna secara statistik maupun secara praktis. Hasil analisis model 3 menunjukkan bahwa lama pacaran yang dialami oleh remaja putri mempunyai kemungkinan 
2 kali lebih besar untuk mengalami kecemasan. Model ini memberikan kontribusi terjadinya kecemasan sebesar $12,5 \%$.

Model 4 menggambarkan hubungan antara kekerasan dalam pacaran dengan kecemasan dengan melibatkan sumber informasi. Hasil analisis menunjukkan kekerasan dalam pacaran memiliki hubungan yang bermakna dengan kecemasan. Namun dengan melibatkan variabel sumber informasi tidak ada hubungan yang bermakna secara statistik maupun secara praktis. Hasil analisis model 4 menunjukkan bahwa sumber informasi mempunyai kemungkinan 0,5 kali lebih besar untuk mengalami kecemasan. Model ini memberikan kontribusi terjadi kecemasan sebesar $13 \%$.

Berdasarkan dari hasil permodelan diatas, maka dapat dilihat model 2 yang lebih baik untuk digunakan sebagai bahan pertimbangan dalam melakukan intervensi. Model 2 memberikan kontribusi terjadi kecemasan sebesar $18,7 \%$, dengan kata lain bahwa besarnya pengaruh yang diberikan oleh variabel umur sebesar $18,7 \%$ sementara ada $81,3 \%$ faktor lain yang tidak diteliti dalam penelitian ini yang dapat mempengaruhi kecemasan remaja putri.

\section{1) Hasil Wawancara Mendalam (Data Kualitatif)}

Seluruh Responden bertempat tinggal di Kabupaten Purworejo. Kesimpulan hasil wawancara terhadap 2 Responden dalam penelitian kualitatif yaitu adanya pernyataan yang sama terhadap pengalaman kekerasan dalam pacaran dan kecemasan.

\section{a) Pengalaman Kekerasan dalam Pacaran}

Berupa tindakan verbal seperti yang diungkapkan berikut ini:

"...Dulu pernah dia memarahi saya, tetapi kata-katanya sangat kasar, semua kebun binatang keluar, tapi setelah itu dia bilang kalau dia buat gitu karena dia sayang sama saya...."

(Responden 1)

"... dia pernah mengancam saya, dan memaksa saya untuk minum obat itu...dia juga marah-marah sama saya..."

(Responden 2)

Tindakan non verbal yang dilakukan oleh pacar diungkapkan sebagai berikut:

“...dia selingkuh... trus dia berduaan di dalam kelas waktu saya datang ke tempatnya sehabis jam pulang sekolah... e... dia terus malah marah dan dia mukul meja dan mencaci maki saya di depan temen perempuannya yang baru..."

(Responden 1)

“...dia membawa saya ke rumahnya waktu ortunya gak ada dirumah, lalu dia mengunci pintu trus dia mulai menciumi saya dan membuka baju saya secara paksa... dia mengancam dan memaksa saya supaya mau melakukan 
hubungan seks dengannya, dia mengancam kalau tidak, saya akan disudut rokok... akhirnya kamipun melakukan hal itu, dia bilang dia mau bertanggung jawab karena dia sangat mencintai saya, tetapi sejak dari kejadian itu dia mulai ingkar janji, tidak bisa dihubungi...dia juga mulai mencari-cari kesalahan bu..., akhirnya dia memutuskan hubungan kami..."

(Responden 2)

Kekerasan dalam pacaran tidak selamanya terjadi secara murni atau terjadi begitu saja tanpa faktor pemicu kekerasan lainnya. Kekerasan dalam pacaran dapat terjadi karena faktor jarak antara individu yang berpacaran berjauhan, dan hal ini mengakibatkan gangguan komunikasi di dalam hubungan pacaran, seperti yang diungkapkan berikut ini:

"...Dulu saya punya pacar tapi pindah ke Cirebon, jadi kamipun pacaran jarak jauh, tapi setelah beberapa bulan saya selalu dicurigai, dituduh-tuduh padahal yang dia pikir gak ada satupun yang saya lakukan..."

(Responden 1)

Kekerasan dalam pacaran selain dilakukan secara langsung dan terbuka, dapat juga dilakukan secara terselubung dibalik penyangkalan terjadinya perselingkuhan dan dibalik ucapan rasa sayang kepada pacar, seperti yang diungkapkan berikut ini:

"...dia mencubit saya sampai biru, terus setelah diliatin ke dia tapi dia bilang, biarin aja itukan sebagai tanda sayang dia ke saya, jadi kalau saya liat bekas cubitan itu saya jadi inget dia..."

(Responden 1)

Perilaku posesif dapat berupa mengawasi setiap aktifitas pacar, membatasi pergaulan, sampai kepada larangan untuk bergaul dengan orang-orang tertentu. Namun, perilaku posesif terkadang didasari oleh nilai positif yang terselubung dibalik perilaku ini. Hal ini seperti yang diceritakan berikut ini:

"dia selalu marah kalau saya online, katanya mau cari cowok lagi. Pokoknya kalau dia yang online gak papa tapi kalau saya yang online selalu dilarang, selain itu kalau saya pergi pasti ditanya-tanya sampek saya males jawabnya..."

(Responden 1)

Kekerasan dalam pacaran dapat tercetus karena adanya desakan dari pacar sendiri yang menuntutnya untuk mengambil keputusan yang sangat mendesak sehingga melakukan suatu kekerasan. Hal ini seperti diceritakan berikut ini:

"... Saya pernah pura-pura sedang haid saat dia minta 
untuk berhubungan tetapi dia tetap memaksa dengan menggunakan kondom, ntah darimana dia dapatkan yang penting saya liat dia dah pegang kondom, tapi saya buruburu lari pulang..."

(Responden 2)

b) Pengalaman Kecemasan Setelah Mengalami Kekerasan dalam Pacaran

Kekerasan dalam pacaran menimbulkan dampak psikologis, Hal ini seperti diungkapkan oleh responden 1 ketika diberikan pertanyaan: Apakah dampak psikologis yang anda rasakan setelah dilakukan kekerasan oleh pacar anda?

“...Beberapa bulan saya membenci semua laki-laki. Saya berfikir semua cowok brengsek dan pembohong, yang ada dalam otak saya hanya itu tidak lebih...."

(Responden 1)

“...Sebenarnya saya juga takut sama Tuhan dan menyesal dengan apa yang uda terjadi tetapi mau bagaimana lagi toh semua uda terjadi, yang jelas kalau saya melihat laki-laki kejadian yang pahit-pahit itu terekam kembali diingatan saya..."

(Responden 2)

Tingkat keparahan dari efek kekerasan dalam pacaran bermacam-macam. Seperti yang diungkapkan sebagai berikut:

“...Ada beberapa laki-laki yang mau deket dengan saya bahkan orang tua juga sudah tau, tapi saya merasa belum bisa menerima dia dengan baik, karena bayang-bayang dimasa lalu..."

(Responden 1)

Efek kekerasan dalam pacaran dapat mempengaruhi kehidupan sehari-hari. Kegiatan sehari-hari terganggu, hal ini dirasakan dan diungkapkan dalam hasil wawancara berikut:

“...saya sering mengalami tidur terganggu, dan juga sering merenung. kejadian itu selalu menghantui sehingga membuat saya menangis...."

(Responden 1)

"...saya susah tidur, gak bisa makan... pokoknya saya hanya memikirkan peristiwa itu, koq bisa dia begitu ya?... dan saya lebih banyak melamun...sejak itu, saya koq gak bisa menerima cowok lain ya..."

(Responden 2) 
Korban kekerasan dalam pacaran meninggalkan kecemasan, trauma dan mempengaruhi kehidupan sehari-hari. Lamanya dampak kecemasan dirasakan oleh korban dipengaruhi oleh usia korban itu sendiri, seperti pengalaman berikut ini:

"...Saya merasakan sampai 3 bulan dan tidak bisa percaya lagi sama cowok...walaupun sekarang saya mencoba menjalin hubungan sudah hampir 6 bulan ini, kadang saya merasa lebih baik..."

(Responden 1, usia 15 tahun)

“... saya jadi jutek dengan laki-laki, sampai 2 bulan saya belum sembuh, dan masih memikirkan mantan terus...tapi saya sudah coba untuk pacaran lagi sih...dan menerima dengan ikhlas..."

(Responden 2, usia 17 tahun)

\section{B. PEMBAHASAN}

Kecemasan dapat berupa menarik diri dari lingkungan sekitar, ketidakmampuan untuk melakukan suatu kegiatan yang berakibat perilaku tidak sehat seperti berat badan tidak terkendali, alkoholik dan masalah-masalah kesehatan lain. $^{7}$

Angka kekerasan dalam pacaran di Sumatera Selatan sebanyak 52 kasus. Jumlah ini meningkat dibandingkan dengan tahun 2008 hanya sebanyak 22 kasus. ${ }^{5}$ Meningkatnya angka kekerasan dalam pacaran pada remaja putri karena banyak korban (remaja) yang dipaksa atau dibujuk melakukan hubungan intim saat berpacaran. ${ }^{10}$ Remaja yang berisiko lebih tinggi terhadap kekerasan dalam pacaran umumnya terjadi pada usia 15-16 tahun. ${ }^{8}$

Hasil distribusi frekuensi menunjukkan lebih dari setengah responden $(63 \%)$ mengalami kekerasan dalam kategori sedang. Bentuk kekerasan yang dialami oleh remaja putri meliputi kekerasan fisik, seksual, emosional/psikologis dan ekonomi. Hal serupa bahwa sebagian besar remaja mengalami lebih dari satu bentuk kekerasan baik kekerasan fisik ataupun kekerasan psikologis yang semuanya itu berdampak pada kecemasan dan depresi. ${ }^{9}$

Berdasarkan penelitian ini menunjukkan bahwa bentuk kekerasan yang paling banyak dialami oleh remaja putri adalah kekerasan seksual sebesar $34,17 \%$. Hasil ini berbeda dengan perempuan korban kekerasan dalam pacaran sering melaporkan bahwa kekerasan psikologis lebih merusak daripada kekerasan fisik dan merupakan sumber penderitaan yang paling berat dalam pacaran. ${ }^{10}$ Hasil ini berbeda dengan pendapat yang menyatakan bahwa sebagian besar perempuan di klinik yang melaporkan mengalami bentuk kekerasan fisik dibandingkan kekerasan lainnya. $^{9}$

Resiko gangguan depresi dan kecemasan pada korban kekerasan fisik 2,56 kali lebih besar dibandingkan kekerasan psikologi/emosional di fasilitas psikiatrik. ${ }^{11}$ Faktor ekonomi pada masyarakat asli Amerika kondisi sosial ekonomi yang buruk merupakan penyumbang utama tingginya tingkat kekerasan ekonomi di kalangan wanita asli Amerika. ${ }^{12}$

Penelitian ini juga menunjukkan bahwa kasus kecemasan lebih banyak dialami pada remaja pertengahan pada usia 14-16 tahun sebesar $82 \%$. Begitu pula dengan perasaan cemas yang dialami remaja berbeda dengan rasa takut, takut merupakan penilaian intelektual terhadap sesuatu yang berbahaya, 
sedangkan rasa cemas merupakan respon emosional terhadap penilaian suatu obyek. $^{7}$

Hasil bivariabel menunjukkan lama pacaran yang dialami oleh remaja putri sebagian besar kurang dari satu tahun (71,58\%). $77 \%$ remaja yang pacaran melaporkan perilaku kekerasan psikologis, fisik dan seksual oleh pasangannya selama satu tahun terkahir. ${ }^{11}$ Begitu pula dengan pendapat yang lain sebanyak 273 wanita yang memiliki pasangan atau pacar memiliki riwayat kekerasan selama kurang dari satu tahun. ${ }^{12}$

Sumber informasi yang didapat remaja putri berdasarkan penelitian ini bukan dari orang tua melainkan dari media massa (media cetak dan media elektronik) sebanyak $23,46 \%$. Hal ini berbeda dengan intervensi kekerasan dalam pacaran meningkatkan ikatan orang tua dan anak untuk menghindari eksternalisasi dan melindungi mereka dari kekerasan pada umumnya. ${ }^{2}$

Hasil uji biivariabel dalam penelitian ini menunjukkan bahwa proporsi kecemasan berpeluang terjadi pada remaja yang mengalami kekerasan dalam pacaran 3 kali lebih tinggi. Hasil ini diperkuat dengan risiko gangguan depresi dan kecemasan adalah 3,39 kali lebih besar pada korban kekerasan fisik, seksual dan emosi/psikologis. ${ }^{11}$ Hasil ini sesuai dengan penelitian WHO yang menunjukkan bahwa kekerasan emosi/psikologis berdampak pada gangguan kesehatan mental perempuan, seperti depresi, kecemasan, phobia dan gangguan stress pasca trauma. Efek psikologis yang berkepanjangan dapat mempengaruhi sikap dan perilaku perempuan menjadi negatif. ${ }^{13}$ Hasil ini juga diperkuat dengan wawancara mendalam berikut:

"...saya sering mengalami tidur terganggu, dan juga sering merenung. kejadian itu selalu menghantui sehingga membuat saya menangis...."

(Responden 1)

“...saya susah tidur, gak bisa makan... pokoknya saya hanya memikirkan peristiwa itu, koq bisa dia begitu ya?... dan saya lebih banyak melamun...sejak itu, saya koq gak bisa menerima cowok lain ya..."

(Responden 2)

Responden yang mengalami kekerasan dalam pacaran merasa takut dan menangis, susah tidur, membenci laki-laki, tidak percaya pada laki-laki, ada rasa curiga terhadap laki-laki yang ingin mendekat, keterpaksaan untuk melakukan hubungan seksual. Ini berarti bahwa kekerasan dalam pacaran meninggalkan trauma yang mendalam. Hal ini juga dinyatakan bahwa gejala kesehatan mental berkorelasi secara positif dengan setiap tindak kekerasan dan gejala tersebut meningkat secara signifikan dengan kecemasan, depresi, gejala PSTD (gangguan stres pasca trauma) bahkan tindak bunuh diri. ${ }^{14}$

Berdasarkan hasil penelitian biivariabel pada lama pacaran dan sumber informasi tidak berhubungan secara signifikan dengan kecemasan. Berdasarkan hasil yang diperoleh dapat diartikan bahwa kecemasan dapat terjadi pada remaja yang mengalami kekerasan kapan saja. Hal ini berbeda dengan hasil bahwa $77 \%$ remaja yang pacaran melaporkan perilaku kekerasan psikologis, fisik dan seksual oleh pasangannya selama satu tahun terakhir. ${ }^{11}$

Analisis multivariabel menunjukkan bahwa remaja yang mendapat kekerasan dalam pacaran dan mengalami kecemasan sebesar 6 kali. Hal ini berarti bahwa kekerasan dalam pacaran menunjukkan hubungan yang signifikan dengan kecemasan. Hasil sesuai dengan WHO yang menunjukkan 
bahwa kekerasan berdampak terhadap gangguan kesehatan mental perempuan, dimana dapat terjadi depresi, kecemasan phobia dan gangguan stress pasca trauma.

Perempuan yang mengalami kekerasan fisik melaporkan mengalami tingkat stress emosional yang tinggi dibanding perempuan yang tidak mengalami kekerasan. ${ }^{15}$ Pandangan yang serupa bahwa perempuan yang mengalami kekerasan fisik dan seksual dalam pacaran lebih meningkatkan pemikiran yang negatif terhadap diri sendiri dan orang lain baik sekarang maupun di masa depan. ${ }^{11}$

Hasil multivariat ini serupa dengan hasil setelah mengendalikan variabel usia dan kekerasan terhadap pasangan secara bersamaan terdapat hubungan yang signifikan $(\mathrm{OR}=1,86) .{ }^{16}$ Usia remaja putri yang mengalami kekerasan dalam pacaran dalam penelitian ini yaitu usia 14-16 tahun atau termasuk dalam usia remaja pertengahan. Hal ini berbeda dengan penelitian yang menganggap bahwa kekerasan psikologis/emosi berkaitan dengan hubungan yang serius, dan hubungan yang serius cenderung terjadi pada usia dewasa, dan dampak yang terjadi adalah lebih buruk daripada hubungan yang biasa. ${ }^{17}$

OR model 1 dibandingkan OR model 2 mengalami penurunan. Tetapi besarnya penurunan tidak melebihi dari $10 \%$. Begitu juga pada pemodelan 3 dan model 4 yang mengalami penurunan lebih dari $10 \%$, sehingga variable $\mathrm{m}$. usia bukan confounding .

Penelitian ini didukung oleh hasil wawancara mendalam terhadap 2 responden. Responden 1 menyatakan:

"...Saya merasakan sampai 3 bulan dan tidak bisa percaya lagi sama cowok...walaupun sekarang saya mencoba menjalin hubungan sudah hampir 6 bulan ini, kadang saya merasa lebih baik..."

Hasil wawancara diatas berbeda dengan pernyataan klien lain pada tahap usia yang berbeda. Pada klien yang berusia lebih muda mengalami kekerasan dalam pacaran lebih tinggi terhadap kecemasan dibandingkan klien yang berusia lebih tua, seperti hasil wawancara terhadap informan berusia remaja berikut:

“... saya jadi jutek dengan laki-laki, sampai 2 bulan saya belum sembuh, dan masih memikirkan mantan terus...tapi saya sudah coba untuk pacaran lagi sih...dan menerima dengan ikhlas..."

\section{SIMPULAN DAN SARAN}

\section{A. Simpulan}

Berdasarkan hasil analisis dan pembahasan untuk menjawab tujuan penelitian dapat disimpulkan bahwa (1) Gambaran kekerasan fisik dalam pacaran yang dialami oleh remaja putri di Kabupaten Purworejo yaitu dipukul oleh pacar/pasangannya sebanyak $30,83 \%$. (2) Gambaran kekerasan seksual dalam pacaran yang dialami oleh remaja putri di Kabupaten Purworejo yaitu dicium paksa oleh pacar/pasangan sebesar $34,17 \%$. (3) Gambaran kekerasan emosi dalam pacaran yang dialami oleh remaja putri di Kabupaten Purworejo yaitu tanpa kerelaan membelikan pulsa untuk pacar/pasangan sebanyak $25,83 \%$. (4) Gambaran kekerasan emosi dalam pacaran yang dialami oleh 
remaja putri di Kabupaten Purworejo yaitu merasa tersinggung atas perlakuan pacar/pasangan yang menjadikannya sebagai bahan tertawaan di depan umum sebanyak $17,50 \%$. (5)Tingkat kecemasan korban kekerasan dalam pacaran yang dialami oleh remaja putri di Kabupaten Purworejo adalah dalam kategori kecemasan sedang dan mengalami kekerasan dalam pacaran sebesar $62,86 \%$. Ada hubungan antara kekerasan dalam pacaran dan kecemasan secara signifikan dengan kecemasan ( $p=0,0014 \mathrm{RP}=3,1$ dan $95 \% \mathrm{Cl}=1,5-6,3)$.

\section{B. Saran}

Berdasarkan pembahasan dan kesimpulan yang telah dilakukan dalam penelitian ini, maka saran yang dapat diberikan adalah sebagai berikut (1) Kepada para orang tua, tokoh agama dan tokoh masyarakat hendaknya menyediakan waktu secara khusus untuk memberikan informasi, nasehatnasehat dan pemahaman tentang kekerasan dan masalah-masalah sekitarnya kepada remaja putri sehingga mereka memiliki bekal pengetahuan yang cukup mengenai kekerasan yang ada di lingkungan sekitar. (2) Bagi institusi kesehatan diharapkan mengembangkan Puskesmas ramah remaja yang mampu mengintegrasikan penyediaan informasi tentang keselamatan remaja dari tindak kekerasan dengan pelayanan kesehatan wanita dan kesehatan reproduksi remaja. (3) Memberikan informasi sebanyak-banyaknya untuk meningkatkan pengetahuan remaja terhadap kekerasan dalam pacaran serta cara mengatasinya. Khususnya kepada remaja putri yang memiliki pacar/ pasangan, dan menyediakan sarana konsultasi bagi remaja yang mengalami tindak kekerasan sehingga remaja tersebut mampu menciptakan ketegasan diri dan memperluas wawasan diri mengenai isu-isu gender.

\section{DAFTAR PUSTAKA}

1. Burin Peninsula Voice against Woman, Dating Violence, Canada. 2006

2. Maas C. D., Fleming C. B., Herrenkohl T. I., And Catalano R. F., Childhood Predictors Of Teen Dating Violence Victimization. Violence Vict. Available in PMC 2011. 2010

3. Kaplan B.J. \& Saddock V.A.B., Synopsis of Psychiatry, 9th edition, Lippincott Williams \& Wilkins, Philadelphia. 1997

4. Sagala, V.R., Memahami Catatan Awal Tahun 2004, Komnas Perempuan Institut Perempuan, Februari 2004.

5. Rifka Annisa, Annual Report Data Kasus Kekerasan di Women Crisis Center Rifka Annisa, Yogyakarta. 2007

6. Marchira C.R., Amylia Y., Winarso M. S., Hubungan Kekerasan Dalam Rumah Tangga Dengan Tingkat Kecemasan Pada Wanita, Berita Kedokteran Masyarakat, Vol 23. No. 3. September 2007.

7. Stuart, G.W., Sundeen J.S., Buku Saku Keperawatan Jiwa, Edisi 3, EGC, Jakarta. 1998

8. Cohen M.M \& Maclean Heather, Violence Against Canadian Women, BMC Women's Health. 2004

9. Nicolaidis C., Curry M., McFarland B., Gerrity M., Violence, Mental Health, and Physical Symptoms in an Academic Internal Medicine Practice. J Gen Intern Med. Pg 819-827. 2004

10. Shorey, R.C., Cornelius, T.L. \& Bell, K.M., A Critical Review of Theoretical Frameworks for Dating Violence: Comparing The Dating and Marital Fields, Aggress Violent Behav, 12: 185-94. 2008 
11. Rizzo Christie J. Smythers C.E., Spirito Anthony \& Thompson Ariel, Psychiatric and Cognitive Functioning in Adolescent Inpatients with Histories of Dating Violence Victimization, J Aggress Maltreat Trauma. 2010

12. Malcoe Lorraine Halinka, Duran Bonnie $M$ and Montgomery Juliann M., Socioeconomic Disparities in Intimate Partner Violence Against Native American Women: A Cross-Sectional Study, BMC Medicine. 2004

13. WHO, Researching Violence Againts Women. 2005b

14. Houry Debra, MD, MPH, Kemball Robin, MPH,. Rhodes Karin V, MD, MSb, and. Kaslow N. J, MD., Intimate Partner Violence and Mental Health Symptoms in African American Female ED patients, Am J Emerg Med., Available in PMC. 2006

15. WHO. WHO Multi-country Study on Women's Health and Domestic Violence Against Women. 2005a

16. Lehrer J.A, Buka S., Gortmaker S., \& Schrier, Depressive Symphtomatology as a Predictor of Exsposure to Intimate Partner Violence Among United States Female Adolescents and Young Adults: http://www.archpediatrics.com. Arch Pediatric Adolescent Medical Journal. Vol. 160. Maret 2006. Pp. 270-276.

17. Howard D. E \& Wang M.Q., Risks Profiles of Adolescent Girls Who Were Victims of Dating Violence. Journal of Adolescents, 38, 149. 2003 